\title{
Author Correction: Genome-wide association study of knee pain identifies associations with GDF5 and COL27A1 in UK Biobank
}

Weihua Meng (1), Mark J. Adams (1), Colin N. A. Palmer, The 23andMe Research Team, Jingchunzi Shi, Adam Auton, Kathleen A. Ryan, Joanne M. Jordan (1), Braxton D. Mitchell, Rebecca D. Jackson, Michelle S. Yau, Andrew M. Mclntosh (D) \& Blair H. Smith (D)

Correction to: Communications Biology https://doi.org/10.1038/s42003-019-0568-2, published online 28 August 2019.

In the original published version of this article, the alleles shown in the Table 2 column labelled 'Effective allele in all cohorts' was incorrect due to SNP concordance issues. This error has now been corrected in the HTML and PDF versions.

Published online: 26 March 2020

(c) Open Access This article is licensed under a Creative Commons Attribution 4.0 International License, which permits use, sharing, adaptation, distribution and reproduction in any medium or format, as long as you give appropriate credit to the original author(s) and the source, provide a link to the Creative Commons license, and indicate if changes were made. The images or other third party material in this article are included in the article's Creative Commons license, unless indicated otherwise in a credit line to the material. If material is not included in the article's Creative Commons license and your intended use is not permitted by statutory regulation or exceeds the permitted use, you will need to obtain permission directly from the copyright holder. To view a copy of this license, visit http://creativecommons.org/licenses/by/4.0/.

(c) The Author(s) 2020 